Original Article

\title{
EFFECTIVENESS OF MASSAGE THERAPY ON RESPIRATORY STATUS AM ONG TODDLERS WITH LOWER RESPIRATORY TRACT INFECTION
}

\author{
Helen Martina M A ${ }^{1}$, Hepzibah Beulah ${ }^{2} \&$ Anita David $^{3}$ \\ ${ }^{1}$ Post Graduate, ${ }^{2,3}$ Readers, Department of Paediatric Nursing, Faculty of Nursing, College of Nursing, \\ Sri Ramachandra University, Porur, Chennai, Tamil Nadu. \\ Correspondence : \\ Hepzibah Beulah \\ Reader, Faculty of Nursing, College of Nursing, Sri Ramachandra University, Porur, Chennai, Tamil Nadu \\ E-mail : hepzijones@gmail.com
}

\begin{abstract}
:
Lower respiratory tract infection is one of the major prevailing respiratory illnesses in children. The aim of the study is to assess the effectiveness of massage therapy on respiratory status among toddlers with lower respiratory tract infection. A sample of 60 toddlers were conveniently assigned to study and control group, in study group routine care and massage therapy was performed for three days in morning and evening then posttest was conducted end of each day whereas control group receives routine care. The result showsthat massage therapy was significantly effective in improving lung functions.
\end{abstract}

Keywords: M assage therapy, Lower respiratory tract infection, Respiratory status

\section{Introduction:}

Globally, Respiratory infection causes morbidity and mortality in young children. Majority of under five children were affected with 3 to 8 respiratory illnesses a year, globally 3.9 million deaths occur every year. Children develop five to eight attacks of respiratory illness such as bronchiolitis, asthma and pneumonia which causes 30 $40 \%$ of hospitalization. Lower respiratory tract infection is more fatal than upper respiratory infection. M oreover in $2013,6.9 \%$ of death due to respiratory illness which is the leading cause when compare to other diseases. Lower respiratory tract infection manifests symptoms like wheezing, fever, tachypnea, chest retraction.

Massage therapy is a complementary and alternative treatment "the manual manipulation of soft tissue

Access this article online Quick Response Code

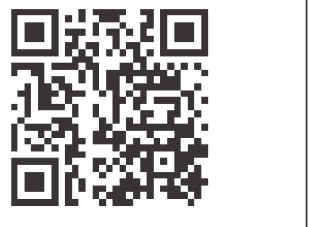

intended to promote health and well-being" for children. M assage therapy consists of five steps such as effleurage, petrissage, stroking, and kneading, which improves lung function, promotes relaxation, enhance healing process and well-being. It focuses on relaxing the muscles engaged in breathing and prevents stimulating the trigger points.

\section{Conceptual Framework:}

Ernestine Wiedenbach conceptual model of nursing was adopted "the helping art of clinical nursing". It consists of four phases such as identification, ministration, validation and feedback.

Identification in this phase, the initial assessment of respiratory status such as nasal flaring, chest retraction, respiratory rate, heart rate, lung auscultation of the children who were diagnosed as lower respiratory tract infection. In ministration phase massage therapy is given by efflurage, pertrissage, kneading, stroking for 5 mins in chest and 5mins in back both in the morning and evening to the study group along routine care. Validation phase of the study where the effect of massage therapy on respiratory status of toddlers with lower respiratory tract infection was assessed. The final phase, feedback of the study to modify the care in the present or future.

\section{Materials And Methods:}

Research design adopted for the study was Pretest Posttest 
control group design. The information was gathered from the paediatric ward at Sri Ramachandra Hospital, Chennai. Using convenient sampling method 60 toddlers were selected, study group 30 and control group 30 respectively. The pretest was conducted using demographic variables and assessing respiratory status of toddlers with the help of M odified Silverman Score. It consists of five variables such as nasal flaring, chest retraction, heart rate, respiratory rate, lung auscultation. The interpretations of scores were like 0-3 mild, 4-6 moderate and 7-10 severe. The reliability of the tool was 0.85

Massage therapy which consists of four steps such as efflurage, pertrissage, kneading and stroking. Each step was performed 10 times for one minute. Massage therapy was performed 5 minutes in chest and 5 minutes in back both twice a day with routine care then a post test was conducted every day after the intervention for three days. Whereas, the control group participants received only routine care and posttest was conducted every day evening for three days. After the third posttest, massage therapy was demonstrated to the mothers of toddlers of the control group.

\begin{tabular}{|c|c|c|c|c|c|c|c|c|c|c|}
\hline \multirow{2}{*}{$\begin{array}{c}\text { Gro- } \\
\text { up }\end{array}$} & \multicolumn{4}{|c|}{ Day 1 } & \multicolumn{3}{c|}{ Day 2 } & \multicolumn{3}{c|}{ Day 3 } \\
\hline M & E & & M & E & & M & E & & \\
\hline C & 01 & $* X$ & $* X$ & 02 & $* X$ & $* X$ & 03 & $* X$ & $* X$ & 04 \\
\hline
\end{tabular}

Key:

$01 \quad$ - Pretest (assessment of respiratory status using modified silverman scale)

* $\quad$ - Routine care

X $\quad$ - Intervention (massage therapy on chest and back for 10mins)

02,03,04 -Posttest 1,2,3

\section{Ethical Consideration :}

The permission was obtained from the institutional ethics committee. Before collecting data, mothers were explained and consent was taken. Confidentiality was assured.

\section{Data Analysis:}

Descriptive statistics- frequency, percentage, means and standard deviation used to assess the respiratory status. Inferential statistics- wilcoxon, mann-whitney, and chisquare used to check the effectiveness and association between the respiratory status and the selected demographic variables.

\section{Results :}

Table I : Frequency and percentage distribution of demographic variables among toddlers in the study and the control groups $(\mathrm{N}=60)$

\begin{tabular}{|c|c|c|c|c|c|c|}
\hline \multirow[t]{2}{*}{ SI No } & \multirow[t]{2}{*}{ Demographic variables } & \multicolumn{2}{|c|}{$\begin{array}{l}\text { Study group } \\
(n=30)\end{array}$} & \multicolumn{2}{|c|}{$\begin{array}{l}\text { Control group } \\
(n=30)\end{array}$} & \multirow{2}{*}{$\begin{array}{c}\mathrm{X}^{2} \\
\alpha \\
\mathrm{p} \text { value }\end{array}$} \\
\hline & & No. & $\%$ & No. & $\%$ & \\
\hline 1. & $\begin{array}{l}\text { Gender } \\
\text { a. Male } \\
\text { b. Female }\end{array}$ & $\begin{array}{l}17 \\
13\end{array}$ & $\begin{array}{l}56.7 \\
43.3\end{array}$ & $\begin{array}{l}18 \\
12\end{array}$ & $\begin{array}{l}60.0 \\
40.0\end{array}$ & $\begin{array}{c}0.069 \\
0.793 \text { (NS) }\end{array}$ \\
\hline 2. & $\begin{array}{l}\text { Type of family } \\
\text { a. Nuclear } \\
\text { b. Joint }\end{array}$ & $\begin{array}{l}12 \\
18 \\
\end{array}$ & $\begin{array}{l}40.0 \\
60.0\end{array}$ & $\begin{array}{l}20 \\
10\end{array}$ & $\begin{array}{l}66.7 \\
33.3\end{array}$ & $\begin{array}{c}6.000 \\
0.500 \text { (NS) }\end{array}$ \\
\hline 3. & $\begin{array}{l}\text { Domicillary } \\
\text { a. Urban } \\
\text { b. Suburban } \\
\text { c. Rural }\end{array}$ & $\begin{array}{l}12 \\
10 \\
08\end{array}$ & $\begin{array}{l}40.0 \\
33.3 \\
29.7 \\
\end{array}$ & $\begin{array}{l}14 \\
14 \\
02\end{array}$ & $\begin{array}{c}46.7 \\
46.7 \\
6.6 \\
\end{array}$ & $\begin{array}{c}4.421 \\
0.110 \\
\text { (NS) }\end{array}$ \\
\hline 4. & $\begin{array}{l}\text { Mother's occupation } \\
\text { a.Home maker } \\
\text { b. Skilled } \\
\text { c. Government employee } \\
\text { d. Private employee } \\
\text { e. Self employed }\end{array}$ & $\begin{array}{l}18 \\
06 \\
00 \\
06 \\
00\end{array}$ & $\begin{array}{l}60.0 \\
20.0 \\
0.0 \\
20.0 \\
0.0\end{array}$ & $\begin{array}{l}19 \\
08 \\
01 \\
01 \\
01\end{array}$ & $\begin{array}{c}63.3 \\
26.8 \\
3.3 \\
3.3 \\
3.3\end{array}$ & $\begin{array}{r}5.884 \\
0.206 \\
\text { (NS) }\end{array}$ \\
\hline
\end{tabular}




\begin{tabular}{|c|c|c|c|c|c|c|}
\hline \multirow[t]{2}{*}{\begin{tabular}{|l} 
SI No \\
\end{tabular}} & \multirow[t]{2}{*}{ Demographic variables } & \multicolumn{2}{|c|}{$\begin{array}{c}\text { Study group } \\
(n=30)\end{array}$} & \multicolumn{2}{|c|}{$\begin{array}{l}\text { Control group } \\
\qquad(n=30)\end{array}$} & \multirow{2}{*}{$\begin{array}{c}\mathrm{X}^{2} \\
\alpha \\
\mathrm{p} \text { value }\end{array}$} \\
\hline & & No. & $\%$ & No. & $\%$ & \\
\hline 5. & $\begin{array}{l}\text { Father's education } \\
\text { a. No formal education } \\
\text { b. Primary } \\
\text { c. Secondary } \\
\text { d. High school } \\
\text { e. Graduate }\end{array}$ & $\begin{array}{l}01 \\
05 \\
13 \\
02 \\
09\end{array}$ & $\begin{array}{c}3.3 \\
16.7 \\
43.3 \\
6.7 \\
30.0\end{array}$ & $\begin{array}{l}04 \\
06 \\
08 \\
06 \\
06\end{array}$ & $\begin{array}{l}13.3 \\
20.0 \\
26.7 \\
20.0 \\
20.0\end{array}$ & $\begin{array}{c}5.681 \\
0.224 \\
\text { (NS) }\end{array}$ \\
\hline 6. & $\begin{array}{l}\text { Father's occupation } \\
\text { a. Skilled } \\
\text { b. Self employed } \\
\text { c. Private employee } \\
\text { d. Government employe } \\
\text { e. Unemployed }\end{array}$ & $\begin{array}{l}02 \\
13 \\
13 \\
02 \\
00\end{array}$ & $\begin{array}{c}6.7 \\
43.3 \\
43.3 \\
6.7 \\
0.0\end{array}$ & $\begin{array}{l}05 \\
05 \\
16 \\
04 \\
00\end{array}$ & $\begin{array}{c}16.7 \\
16.7 \\
53.3 \\
13.3 \\
0.0\end{array}$ & $\begin{array}{c}5.818 \\
0.121 \\
\text { (NS) }\end{array}$ \\
\hline 7. & $\begin{array}{l}\text { Income of parents } \\
\text { a. Below } 5000 \\
\text { b. } 5001-10000 \\
\text { c. }>10001\end{array}$ & $\begin{array}{l}00 \\
20 \\
10\end{array}$ & $\begin{array}{c}0.0 \\
66.7 \\
33.3\end{array}$ & $\begin{array}{l}06 \\
12 \\
12\end{array}$ & $\begin{array}{l}20.0 \\
40.0 \\
40.0\end{array}$ & $\begin{array}{c}8.182 \\
0.017 *\end{array}$ \\
\hline 8. & $\begin{array}{l}\text { Care taker of the child } \\
\text { a. Father } \\
\text { b. M other } \\
\text { c. Grand mother } \\
\text { d. Day care center }\end{array}$ & $\begin{array}{l}02 \\
19 \\
09 \\
00\end{array}$ & $\begin{array}{c}6.7 \\
63.3 \\
30.0 \\
0.0\end{array}$ & $\begin{array}{l}05 \\
20 \\
05 \\
00\end{array}$ & $\begin{array}{r}16.7 \\
66.6 \\
16.7 \\
0.0\end{array}$ & $\begin{array}{c}2.454 \\
0.293 \\
\text { (NS) }\end{array}$ \\
\hline 9. & $\begin{array}{l}\text { Immunization status } \\
\text { a. Upto date } \\
\text { b. Irregular }\end{array}$ & $\begin{array}{l}28 \\
02\end{array}$ & $\begin{array}{c}93.3 \\
6.7\end{array}$ & $\begin{array}{l}27 \\
03\end{array}$ & $\begin{array}{l}90.0 \\
10.0\end{array}$ & $\begin{array}{c}0.218 \\
0.640 \text { (NS) }\end{array}$ \\
\hline 10. & $\begin{array}{l}\text { History of previous hospita } \\
\text { a. Yes } \\
\text { b. No } \\
\text { if yes frequency of } \\
\text { hospitalization } \\
\text { a. Once } \\
\text { b. Twice } \\
\text { c. Thrice } \\
\text { d. >Thrice }\end{array}$ & $\begin{array}{l}03 \\
05 \\
04 \\
02\end{array}$ & $\begin{array}{c}10.0 \\
16.7 \\
13.3 \\
6.7\end{array}$ & $\begin{array}{l}06 \\
07 \\
04 \\
02\end{array}$ & $\begin{array}{c}20.0 \\
23.3 \\
13.3 \\
6.7\end{array}$ & $\begin{array}{c}2.238 \\
0.692 \\
\text { (NS) }\end{array}$ \\
\hline 11. & $\begin{array}{l}\text { Frequency of RTI } \\
\text { a. Once in 3months } \\
\text { b. Once in } 6 \text { months } \\
\text { c. Once in } 12 \text { months } \\
\text { d. Rarely }\end{array}$ & $\begin{array}{l}05 \\
14 \\
01 \\
10\end{array}$ & $\begin{array}{c}16.7 \\
46.7 \\
3.3 \\
33.3\end{array}$ & $\begin{array}{l}02 \\
19 \\
02 \\
07\end{array}$ & $\begin{array}{c}6.7 \\
63.3 \\
6.7 \\
23.3\end{array}$ & $\begin{array}{c}2.906 \\
0.406 \\
\text { (NS) }\end{array}$ \\
\hline 12. & $\begin{array}{l}\text { When you consult doctor } \\
\text { a. Immediately } \\
\text { b. Second day } \\
\text { c. After a week }\end{array}$ & $\begin{array}{l}24 \\
05 \\
01\end{array}$ & $\begin{array}{c}80.0 \\
16.7 \\
3.3\end{array}$ & $\begin{array}{l}12 \\
16 \\
02\end{array}$ & $\begin{array}{c}40.0 \\
53.3 \\
6.7\end{array}$ & $\begin{array}{c}10.095 \\
0.006 * *\end{array}$ \\
\hline
\end{tabular}


Figure 1: Percentage distribution of gender among toddlers in the study and control group $(\mathrm{N}=60)$

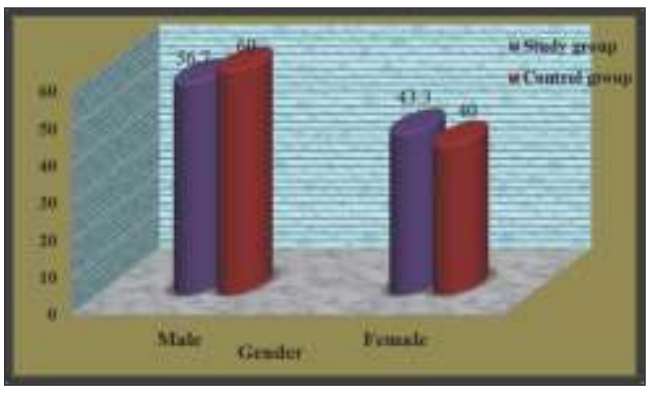

Figure 3: M ean value of nasal flaring among toddlers with lower respiratory tract infection in the study group and control group $(\mathrm{N}=60)$

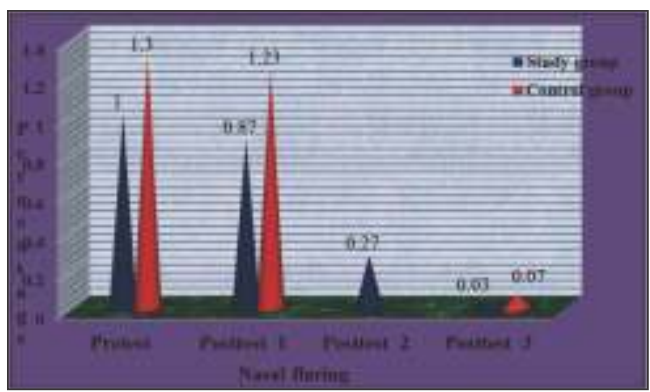

Figure 5 : Mean value of heart rate among toddlers with lower respiratory tract infection in the study group and control group $(\mathrm{N}=60)$

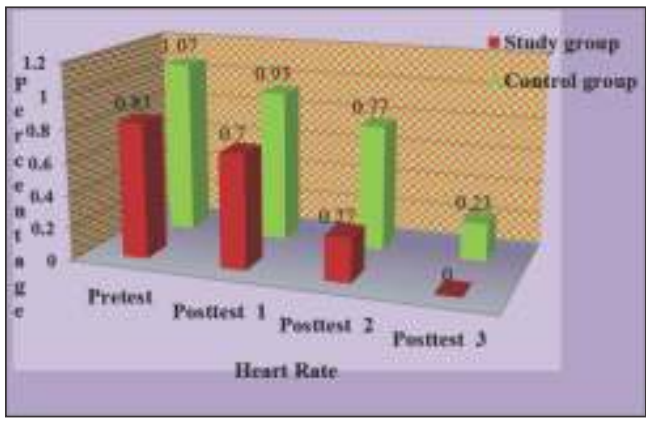

Figure 7 : M ean value of lung auscultation among toddlers with lower respiratory tract infection in the study group and control group $(\mathrm{N}=60)$

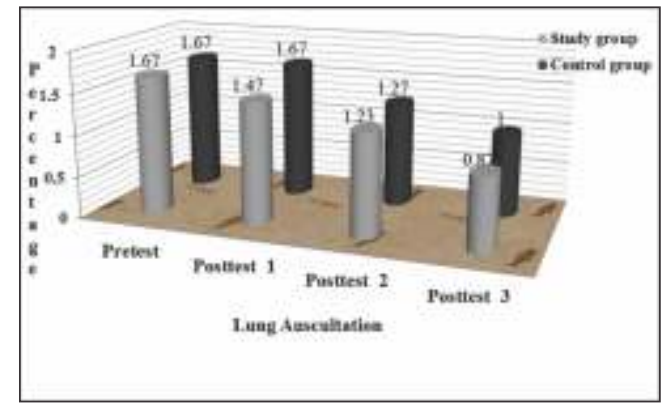

Figure 2: Percentage distribution of mother education among toddlers in the study and control group $(\mathrm{N}=60)$

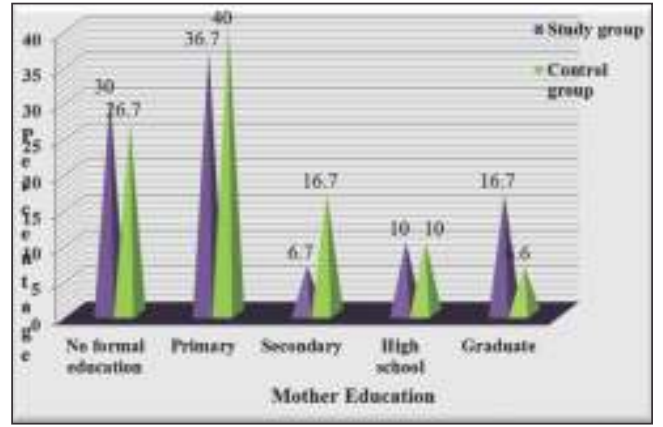

Figure 4: Mean value of chest retraction among toddlers with lower respiratory tract infection in the study group and control $\operatorname{group}(\mathrm{N}=60)$

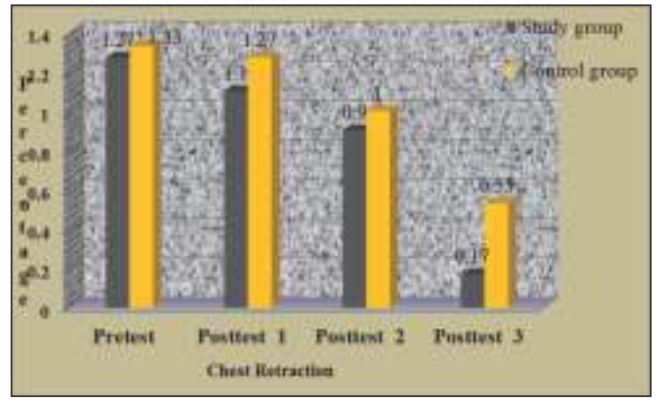

Figure 6 : Mean value of respiratory rate among toddlers with lower respiratory tract infection in the study group and control $\operatorname{group}(\mathrm{N}=60)$

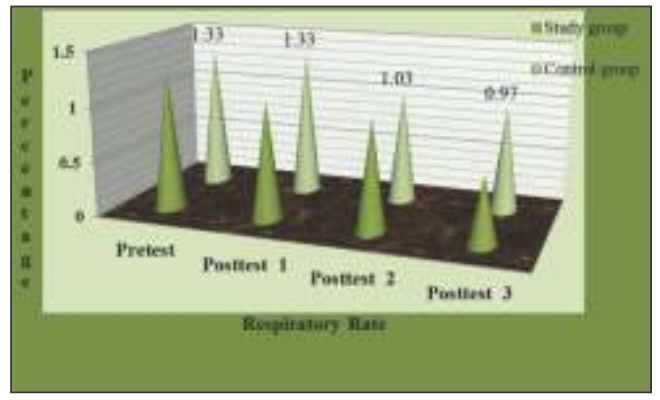

Table II : frequency and percentage distribution of respiratory status among toddlers with lower respiratory tract infection in the study group and control group ( $\mathrm{N}=60$ )

\begin{tabular}{|c|l|c|c|c|c|c|c|}
\hline \multirow{2}{*}{$\begin{array}{l}\text { Duration } \\
\text { of study }\end{array}$} & \multirow{2}{*}{ Group } & \multicolumn{5}{|c|}{ Respiratory status } \\
\cline { 3 - 8 } & & \multicolumn{3}{|c|}{ Mild } & \multicolumn{2}{|c|}{ Moderate } & \multicolumn{2}{c|}{ Severe } \\
\cline { 2 - 8 } & & No. & $\%$ & No. & $\%$ & No. & $\%$ \\
\hline Pretest & Study group & 00 & 0.0 & 21 & 70.0 & 09 & 30.0 \\
\hline & Control group & 00 & 0.0 & 17 & 57.0 & 13 & 43.0 \\
\hline Posttest 1 & Study group & 00 & 0.0 & 26 & 87.0 & 04 & 13.0 \\
\hline & Control group & 00 & 0.0 & 16 & 53.0 & 14 & 47.0 \\
\hline Posttest 2 & Study group & 14 & 47.0 & 16 & 53.0 & 00 & 0.0 \\
\hline & Control group & 00 & 0.0 & 29 & 97.0 & 01 & 3.0 \\
\hline Posttest 3 3 & Study group & 29 & 97.0 & 01 & 3.0 & 00 & 0.0 \\
\hline & Control group & 25 & 83.0 & 05 & 17.0 & 00 & 0.0 \\
\hline
\end{tabular}


Table Il depicts the score of respiratory status among study group. In pretest $21(70 \%)$ had moderate and nine (30\%) had severe respiratory status whereas in control group 17(57\%) had moderate and $13(43 \%)$ had severe respiratory status. During the posttest 3 in the study group 29(97\%) had mild and one (3\%) had moderate respiratory status whereas in control group 25(83\%) had mild and five( $17 \%)$ had moderate respiratory status.

Table III : Mean, Standard deviation and M ann-Whitney $U$ value of M odified Silverman Score of lung auscultation among toddlers with lower respiratory tract infection in the study and the control groups $(\mathrm{N}=60)$.

\begin{tabular}{|c|c|c|c|c|c|}
\hline \multirow{2}{*}{$\begin{array}{c}\text { Respiratory } \\
\text { status }\end{array}$} & \multicolumn{2}{|c|}{$\begin{array}{c}\text { Study group } \\
\text { (n=30) }\end{array}$} & \multicolumn{2}{|c|}{$\begin{array}{c}\text { Control group } \\
(\mathbf{n = 3 0})\end{array}$} & $\begin{array}{c}\text { Mann-Whitney } \\
\text { U and p value }\end{array}$ \\
\cline { 2 - 5 } & Mean & SD & Mean & SD & \\
\hline Pretest & 6.03 & 1.542 & 6.70 & 1.784 & $\begin{array}{c}1.529 \\
0.126(\mathrm{NS})\end{array}$ \\
\hline Posttest 1 & 5.20 & 1.297 & 6.43 & 1.591 & $\begin{array}{c}3.434 \\
0.001^{* *}\end{array}$ \\
\hline Posttest 2 & 3.63 & 1.066 & 4.57 & 0.935 & $\begin{array}{c}3.558 \\
0.000^{* * *}\end{array}$ \\
\hline Posttest 3 & 1.67 & 0.844 & 2.80 & 0.610 & $\begin{array}{c}5.017 \\
0.000 * * *\end{array}$ \\
\hline
\end{tabular}

Table III explicit, in the study group pretest mean $6.03 \pm 1.542$, posttest 1 mean was $5.20 \pm 1.297$, posttest 2 mean was $3.63 \pm$ 1.066 and posttest 3 mean was $1.67 \pm 0.844$, in the control group the pretest mean was $6.70 \pm 1.784$, posttest 1 mean was $6.43 \pm$ 1.591 , posttest 2 mean was $4.57 \pm 0.935$ and posttest 3 mean was $2.80 \pm 0.610$ which were significant at $p \varangle 0.001$ in respiratory status.

\section{Discussion :}

The mean value and standard deviation of respiratory status in the study group among the toddlers with lower respiratory tract infection during the pretest shows that nasal flaring were 1.00 and 0.183 , chest retraction were 1.27 and 0.450 , heart rate were 0.83 and 0.648 , respiratory rate were 1.27 and 0.450 and lung auscultation were 1.67 and 0.479 . whereas in the control group pretest shows that nasal flaring were 1.30 and 0.254 , chest retraction were 1.33 and 0.479 , heart rate were 1.07 and 0.521 , respiratory rate were 1.33 and 0.479 and lung auscultation were 1.67 and 0.479 .

The respiratory status within the study group shows that, the mean value for nasal flaring on the first day during pretest was 1.00 and in the posttest 3 it was 0.03 , the chest retraction mean value was 1.27 in pretest and 0.17 in the posttest day 3 , the mean value for heart rate was 0.83 in the pretest and 0.00 in the posttest 3 , the respiratory rate mean value was 1.27 in the pretest and 0.60 in the posttest 3 and lung auscultation pretest was 1.67 and in the posttest 3 it was 0.87 . The level of significance was $p \varangle 0.001$.

The respiratory status within the control group shows that, the mean value for nasal flaring on the first day during pretest was 1.30 and in the posttest 3 it was 0.07 , the chest retraction mean value was 1.33 in the pretest and 0.53 in the posttest day 3 , the mean value for heart rate was 1.07 in the pretest and 0.23 in the posttest 3 , the respiratory rate mean value was 1.33 in the pretest and 0.97 in the posttest 3 and lung auscultation pretest was 1.67 and posttest 3 was 1.00, which was significant at $p \varangle 0.05$ and $p \varangle 0.01$.The study reveals that massage therapy was effective on respiratory status among toddlers with lower respiratory tract infection.

The study revealed there was an association found between respiratory status and mother's education, care taker of child among toddlers with lower respiratory tract infection in pretest. In the posttest of the study group, there was no association as found between respiratory status and demographic variables.

\section{Nursing Implication :}

Evidenced based practice helps the nurses to enrich them in knowledge and practice. Nurse can utilize massage therapy which improves lung function. Nurses can even teach parents so that when children experience breathing difficulty at home it can help them. Preparation of procedure manual as well as a voice recorded audiotape to the parents which is to be practiced in home can be made. Various seminars, conferences and continuing nursing education can be conducted. Nursing researcher should be aware of the needs and problems of the existing health care system. More research studies can be conducted similar to this study to determine the effectiveness of massage therapy in reducing lower respiratory tract infection.

\section{Recommendations:}

Recommendations for the future study include:

1. A study could be conducted with larger size. 
2. A similar study could be performed for a longer duration.

3. This study could also be conducted as a comparative study using intensive spirometry, deep breathing exercises etc.

\section{Conclusion :}

M assage therapy is a very effective method in reducing the respiratory distress in children. It works in loosening of adhesive respiratory secretions, mobilizing it from peripheral airway to central airway and then removing by upper respiratory tract. This enhances the lung function. This study proves that massage therapy is effective in

\section{References:}

1. Afsaneh Nekooee., (2010), Effect of massage therapy on children with asthma, Journal of Pediatric Nursing, 27(4),209-16.

2. Chattopadhy.D., (2007), Hospitalization of children with lower respiratory tract infection, Pediatric medicine, 15(5), 497-503.

3. Duarte. DM., (2000), Clinical and epidermiological profile of acute respiratory infections, J ournal of pediatric, 34(1), 45-52.

4. Michael Moore., (2008), Predictors of illness duration in acute lower respiratory tract infection, Journal of pediatric nursing, 14(6), 379391.

5. Mohammed. Goldbeck. L.,(2011), Effectiveness of massage therapy on the pulmonary functions of stable children, Journal of American Academy of paediatric, 42(9).1046-54.

6. Patrick. K., Munywoki. Eric. O., Ohuma. (2013), Risk for pneumonia after respiratory syncytial hospitalization, Journal of pediatric nursing, 46(4), 264-73,

7. Piyush Gupta., Nair. MKC., (2011), Indian Academy of Pediatrics Textbook of Pediatrics, $4^{\text {th }}$ edition, Jaypee Brothers M edical Publishers.

8. Polit and Hungler. (1999). Nursing research principles and methods, $6^{\text {th }}$ edition Philadelphia: Lippincott Company.

9. Potter and Perry, (2009), Textbook of fundamental of nursing, $6^{\text {th }}$ edition, Nodia: saurabha printer's Pvt.Ltd

10. Vineetsehgal. G.R., (1996), Predictors of mortality due to acute lower respiratory tract infection, Pediatric medicine,37(2),115-21. improving respiratory status in toddlers with lower respiratory tract infection.

\section{Acknowledgements:}

Its my privilege to thank M anaging Trustee, for permitting me to use available resources in the university.M y heartfelt thanks and gratitude Prof. P.V. Ramachandran, M.Sc (N)., Chairman, Nursing Education, M rs. Hepzibah Beulah, M .Sc (N)., Reader, Department of paediatric nursing and Dr. Anita David, M.Sc (N)., Reader, Department of paediatric nursing, Sri Ramachandra College of Nursing, Sri Ramachandra University for their never ending guidance, support for the research completion. 